\title{
EFFECT OF ARBUSCULAR MYCORRHIZAL FUNGI ON CHEMICAL CONSTITUENTS IN COTTON/ALFALFA MIXED CULTURE
}

\author{
MAZEN IBRAHIM
}

Atomic Energy Commission of Syria, Damascus - Syria

IBRAHIM, M.: Effect of arbuscular mycorrhizal fungi on chemical constituents in cotton/alfalfa mixed culture. Agriculture (Pol'nohospodárstvo), vol. 63, 2017, no. 2, pp. 67-73.

\begin{abstract}
A pot experiment was conducted to study the extent of changes occurring in the nutrients, chlorophyll and protein of plants grown in cotton/alfalfa mixed culture as affected by inoculation with indigenous arbuscular mycorrhizal fungi (AMF). The experiment consisted of mycorrhizal treatments (with and without AMF inoculation) and three planting patterns (cotton monoculture, alfalfa monoculture, cotton/alfalfa mixed culture). Arbuscular mycorrhizal (AM) inoculum previously isolated from a rhizospheric soil of cotton, was a mixture of Glomus intraradices, G. viscosum, and G. mosseae. Results showed that total chlorophyll and protein concentrations, and nutrients content were higher in AM cotton plants compared with the nonAM control. Mixed culture had a positive effect on all the above parameters in cotton shoot. The highest values were noted in AM plants in the mixed culture. Improved chemicals and biochemical constituents in cotton led to an increase in dry matter production. The highest dry matter was observed in the AM mixed culture, and was significantly higher by 1.4 times than that of non-AM monoculture.
\end{abstract}

Key words: cotton, AMF, alfalfa, mixed culture, chlorophyll, nutrients

Sustainable agriculture refers to correct agricultural resource management which it retains environmental quality and capacity of the soil and water resources (Reijntjes et al. 1992). Legume and non-legume intercropping cultivation has been widely encouraged in sustainable agriculture because it has the potential to allow plants to use soil nitrogen $(\mathrm{N})$ more efficiently and improve the yield (Hauggaard-Nielsen et al. 2009; Gao et al. 2014). The productivity of agricultural lands can be improved in mixed culture system if the plants that are combined in this system do not compete each other for sunlight, water and nutrients. The plants which have the most differences in the use of resources, are compatible plants in intercropping (Vandermeer 1989).

Alfalfa is an important forage legume due to its nutritional quality, high protein content and adaptability to soil and climatic conditions (McDonald et al. 1991). Cotton is a mycotrophic plant (Siqueira et al. 1986) in which growth and nutrient uptake is usually increased by arbuscular mycorrhizal fungi (AMF) colonization. In sustainable agriculture, the AMF plays a key role in helping plants to efficiently recycle nutrients and thus remain productive under adverse conditions (Mosse 1986). AMF support $\mathrm{N}_{2}$ fixation by legumes through providing plants with phosphorus and other immobile nutrients such as copper and zinc that are essential for $\mathrm{N}_{2}$ fixation (Clark \& Zeto 2000). The productivity of AM plants may be improved if micronutrient uptake is elevated, resulting in more competitive plants. Micronutrients are involved in biochemical and physiological functions such as biosynthesis of proteins, chlorophyll, and carbohydrate metabolism (Rengel 1999; Parmar et al. 2012). Also, the photosynthesis is affected by micronutrients through various modes of action. The increase of leaf chlorophyll content improves photo 
synthesis, and finally, the yield increases (Tilak et al. 1992). Elevated protein content by mixed culture (Herbert et al. 1984) could indicate the importance of this culture pattern in improving quality of crops.

AMF inoculation of legume/non legume mixed culture and the resulting changes in plant biochemicals and nutrients status, could influence the growth of mixed plants.

The objective of this research was to study the effect of inoculation with indigenous AMF on some chemical and biochemical constituents in cotton (main crop) and alfalfa (associated crop) plants grown in mono and mixed culture.

\section{MATERIAL AND METHODS}

The experiment was conducted during the summer season 2012 at Der-Alhajar research Station,

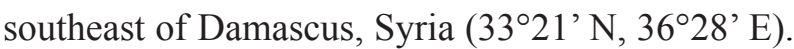
The area is located within an arid region in which the total annual precipitation (in winter) is $120 \mathrm{~mm}$. The average minimum temperature in winter is $1.3^{\circ} \mathrm{C}$ in January, increasing to an average of $36^{\circ} \mathrm{C}$ during August. Plastic pots were filled with $7 \mathrm{~kg}$ of dry topsoil $(0-25 \mathrm{~cm})$ collected from the field which had been planted with alfalfa. The soil was sandy clay with $\mathrm{pH}$ of 7.6 , and contained $10.1 \mathrm{~g} / \mathrm{kg}$ of organic matter, $0.9 \mathrm{~g} / \mathrm{kg}$ of total $\mathrm{N}, 13.3 \mathrm{mg} / \mathrm{kg}$ of available $\mathrm{N}, 11.8 \mathrm{mg} / \mathrm{kg}$ of available $\mathrm{P}$.

\section{AM inoculum preparation}

The arbuscular mycorrhizal inoculum including Glomus intraradices (Schenck \& Smith), G. viscosum (Nicolson), and G. mosseae (Nicol. \& Gerd.) Gerd. \& Trappe, was previously isolated from a rhizospheric soil of cotton (Ibrahim 2010). For propagating AMF, pot-cultures were established by mixing original soil samples with sterilized sand as a substrate for growth of onion (Allium cepa L.) as the trap plant. Pot-cultures were conducted during two successive cycles of 4 months. The substrate containing onion root fragments, mycelium and spores were air dried and used as inoculum. The number of infective propagules in the inoculum was done by employing the most-probable-number technique (Sieverding 1991). The inoculum contained 560 propagules per $100 \mathrm{~g}$ of substrate.

\section{Planting procedures}

Seeds of cotton (Gossypium hirsutum L. Aleppo 33/1) and alfalfa (Medicago sativa L.) were surface sterilized by immersion in $20 \% \mathrm{NaOCl}$ for $1 \mathrm{~min}$ before sowing. Five seeds of alfalfa and three seed of cotton were sown per pot. Half of the pots received the AM inoculum ( $100 \mathrm{~g}$ per pot) by layering at $10 \mathrm{~cm}$ depth of the pots at the time of sowing. Because of very low number of AM propagules in soil, soil for non-AM plants was not pasteurized. Each non-inoculated pot received the same amount of sterilized AM inoculum. Because abundant nodules have been previously observed on the roots of alfalfa grown at the field from which the soil was collected, the seeds were not inoculated with rhizobium. After emergence, the alfalfa seedlings were thinned to three plants per pot and the cotton seedling were thinned to one plant per pot. Plants were watered as needed until sampling date.

\section{Experiment design and treatments}

The experiment was designed into a randomized complete block design with four replicates. The experiment consisted of two treatments of mycorrhiza (with and without) and three planting patterns (cotton monoculture, alfalfa monoculture, cotton-alfalfa mixed culture). The experiment involved six treatments: (i) cotton monoculture, (ii) cotton monoculture with AMF, (iii) alfalfa monoculture, (iv) alfalfa monoculture with AMF, (v) cotton/alfalfa mixed culture, and (vi) cotton/alfalfa mixed culture with AMF.

\section{Determination of chlorophyll concentration}

To determine the concentrations of chlorophyll a (Chl a), chlorophyll b (Chl b), and total chlorophyll in cotton leaves, discs $(100 \mathrm{mg})$ were cut from the upper-most fully expanded leaves randomly selected from three plants of each treatment. Discs were macerated in $5 \mathrm{~mL}$ acetone $(80 \%)$ for $24 \mathrm{~h}$. The absorbance of the pooled extracts was measured at 663 and $645 \mathrm{~nm}$ using a spectrophotometer (Thermo Spectronic, UK). The concentrations of $\mathrm{Chl}$ a, $\mathrm{Chl}$ $\mathrm{b}$, and total chlorophyll were determined using the equations of Arnon (1949).

\section{Plant sampling and analysis}

All plants were sampled by cutting stems at soil level. Plants of both species were sampled at the 
flowering stage of cotton. Above-ground biomass was measured after drying to a constant weight at $70^{\circ} \mathrm{C}$. Crude protein was estimated by multiplying 6.25 by total $\mathrm{N}$ which was measured using micro-Kejeldahl method. $\mathrm{Ca}, \mathrm{K}, \mathrm{Fe}, \mathrm{Zn}, \mathrm{Cu}$, and Mn were determined by X-ray fluorescence (XRF) (Khuder et al. 2009). The determination of phosphorus was based on the colorimetric method first proposed by Misson (1908) using spectrophotometer (ThermoSpectronic, UK).

\section{Determination of mycorrhizal colonization}

Roots samples were rinsed, cut into $1 \mathrm{~cm}$ fragments, totally mixed, cleared with $\mathrm{KOH}$ and stained with acid fuchsine in lactoglycerol. The percentage of root colonization was determined microscopically using a gridline intercept method (Giovannetti \& Mosse 1980).

\section{Statistical Analysis}

The data were analysed by the analysis of variance (ANOVA) using SAS program (SAS Institute Inc, 2004), and means were compared by the least significant difference (Fisher's PLSD) test at a confidence level of $5 \%$.

\section{RESULTS}

\section{Mycorrhizal colonization}

Root colonization by AMF occurred in all treatments including non-inoculated plants (Table 1). The latter plants showed a low colonization level (less than 2\%). Percent AMF colonization of cotton was significantly increased when plants were grown in mixed culture (Table 1). The root colonization was 33.8 and $35.5 \%$ in mono and mixed culture, respectively.

\section{Chlorophyll and crude protein concentrations}

The effects of AMF and pattern of culture were significant on cotton chlorophyll a and total chlorophyll concentration (Table 1). Higher concentrations of chlorophyll a and total chlorophyll were observed in AM plants compared to non-AM plants. Also, the concentrations of chlorophyll a and total chlorophyll were higher in mixed culture than that of monoculture regardless of AMF inoculation. The maximum chlorophyll value was obtained in AM mixed culture with mean of 9.93 , and $14.3 \mathrm{mg} / \mathrm{g}$ fresh matter for chlorophyll a and total chlorophyll, respec-

$\begin{array}{llllll}\mathrm{T} & \mathrm{a} & \mathrm{b} & 1 & \mathrm{e} & 1\end{array}$

Effect of AMF and planting pattern on AMF colonization, above ground dry matter (DM), crude protein and chlorophyll ( $\mathrm{a}, \mathrm{b}$, total) concentrations, and chlorophyll ratio $\mathrm{a} / \mathrm{b}$

\begin{tabular}{|c|c|c|c|c|c|c|c|c|}
\hline \multirow{2}{*}{ Planting pattern } & \multirow{2}{*}{$\begin{array}{c}\mathrm{AMF} \\
\text { inoculation }\end{array}$} & \multirow{2}{*}{$\begin{array}{c}\mathrm{AMF} \\
{[\%]}\end{array}$} & \multirow{2}{*}{$\begin{array}{c}\mathrm{DM} \\
{[\mathrm{g} / \mathrm{pot}]}\end{array}$} & \multirow{2}{*}{$\begin{array}{c}\text { Protein } \\
{[\mathrm{mg} / \mathrm{g} \mathrm{DM}]}\end{array}$} & Chl a & $\mathrm{Chl} \mathrm{b}$ & Total chl & $\mathrm{a} / \mathrm{b}$ \\
\hline & & & & & \multicolumn{4}{|c|}{$[\mathrm{mg} / \mathrm{g} \mathrm{FM}]$} \\
\hline Cotton monoculture & Non-AMF & $1.5^{\mathrm{c}}$ & $6.52^{\mathrm{d}}$ & $10.20^{\mathrm{d}}$ & $8.05^{\mathrm{c}}$ & $3.68^{b}$ & $11.73^{\mathrm{c}}$ & $2.19^{\mathrm{c}}$ \\
\hline Cotton monoculture & $\mathrm{AMF}$ & $33.8^{\mathrm{b}}$ & $11.81^{\mathrm{b}}$ & $10.85^{\mathrm{c}}$ & $9.54^{\mathrm{b}}$ & $3.65^{\mathrm{b}}$ & $13.19^{b}$ & $2.61^{\mathrm{a}}$ \\
\hline Cotton mixed culture & Non-AMF & $1.7^{\mathrm{c}}$ & $9.94^{\mathrm{c}}$ & $11.65^{\mathrm{b}}$ & $9.61^{\mathrm{b}}$ & $3.89^{\mathrm{b}}$ & $13.50^{\mathrm{b}}$ & $2.49^{\mathrm{ab}}$ \\
\hline Cotton mixed culture & AMF & $35.5^{\mathrm{a}}$ & $15.67^{\mathrm{a}}$ & $13.51^{\mathrm{a}}$ & $9.93^{\mathrm{a}}$ & $4.38^{\mathrm{a}}$ & $14.30^{\mathrm{a}}$ & $2.27^{\mathrm{bc}}$ \\
\hline$L S D_{(0.05)}$ & & 1.4 & 0.62 & 0.31 & 0.21 & 0.42 & 0.45 & 0.27 \\
\hline Alfalfa monoculture & Non-AMF & $1.6^{\mathrm{b}}$ & $1.21^{\mathrm{b}}$ & $15.69^{\mathrm{d}}$ & - & - & - & - \\
\hline Alfalfa monoculture & AMF & $27.0^{\mathrm{a}}$ & $2.27^{\mathrm{a}}$ & $17.54^{\mathrm{c}}$ & - & - & - & - \\
\hline Alfalfa mixed culture & Non-AMF & $1.4^{\mathrm{b}}$ & $1.07^{\mathrm{b}}$ & $18.65^{\mathrm{b}}$ & - & - & - & - \\
\hline Alfalfa mixed culture & $\mathrm{AMF}$ & $25.7^{\mathrm{a}}$ & $2.17^{\mathrm{a}}$ & $20.33^{\mathrm{a}}$ & - & - & - & - \\
\hline$L S D_{(005)}$ & & 1.7 & 0.14 & 0.87 & - & - & - & - \\
\hline
\end{tabular}

Means within a column followed by different letters are significantly different $(P<0.05)$; LSD - least significant difference; FM - fresh matter 
tively (Table 1). Chlorophyll ratio a:b decreased in AM plants grown in mixed culture (Table 1). AM mixed culture showed higher concentrations of crude protein in comparison with the other treatments (Table 1). Higher protein concentration was observed in alfalfa compared to that in cotton in all treatments. The maximum protein values were observed in AM mixed culture with mean of 20.33 and $13.51 \mathrm{mg} / \mathrm{g}$ in alfalfa and cotton, respectively (Table 1).

\section{Cotton and alfalfa shoot dry matter}

AMF inoculation increased significantly shoot dry matter of cotton regard less of culture pattern (Table 1). Cotton shoot dry matter in the mixed culture was significantly higher than that of monoculture whether inoculated or not. The highest shoot dry matter of cotton was observed in the AM mixed culture, and was significantly higher by 1.4 times than that of non-AM monoculture treatment (Table 1). AMF also significantly improved the dry matter of the alfalfa shoots compared to the nonAM treatments (Table 1). Alfalfa dry matter was significantly higher by 0.8 times in AM mixed culture than that of non-AM monoculture.

\section{$P, K, C a$ and selected micronutrients content}

AMF produced significant increase in $\mathrm{P}$ content of cotton and alfalfa regardless of culture pattern
(Table 2). Also, AMF inoculation increased the content of $\mathrm{K}, \mathrm{Ca}, \mathrm{Mn}, \mathrm{Fe}, \mathrm{Cu}$, and $\mathrm{Zn}$ in shoot of cotton and alfalfa in both monoculture and mixed culture (Table 2). Mixed culture increased all selected nutrients content in cotton shoot. The highest values were observed in the AM mixed culture (Table 2). In contrast, $\mathrm{K}, \mathrm{Ca}$ and selected micronutrients content in alfalfa shoot decreased in AM mixed culture compared to AM monoculture (Table 2).

\section{DISCUSSION}

The colonization rate achieved by AMF, might indicate adaptation of the indigenous fungi to their native soils in the sense of benefiting their hosts best under these given soil conditions. Numerous researches showed that AMF differ in their ability to inoculate particular plant species and that AMF tend to exhibit the highest response in their soils of origin (Bohrer et al. 2003; Klironomos et al. 2003). The present study showed that AMF colonization was increased when cotton plants were grown in mixed culture. This result agrees with that of Derelle et al. (2015) who showed a positive influence of mixed cultures on AMF root colonization compared with monoculture.

$\mathrm{T}$ a

Effect of AMF and planting pattern on nutrients content in cotton and alfalfa shoot

\begin{tabular}{|c|c|c|c|c|c|c|c|}
\hline \multirow{2}{*}{ Treatment } & $P$ & $\mathrm{~K}$ & $\mathrm{Ca}$ & $\mathrm{Mn}$ & $\mathrm{Fe}$ & $\mathrm{Cu}$ & $\mathrm{Zn}$ \\
\hline & \multicolumn{7}{|c|}{ Nutrient content in cotton $[\mathrm{mg} /$ nutrient/pot $]$} \\
\hline Monoculture & $17.01^{\mathrm{d}}$ & $147.3^{\mathrm{d}}$ & $183.3^{\mathrm{d}}$ & $0.3584^{\mathrm{d}}$ & $1.4435^{\mathrm{d}}$ & $0.029^{c}$ & $0.1984^{\mathrm{d}}$ \\
\hline Monoculture + AMF & $39.52^{\mathrm{b}}$ & $282.5^{\mathrm{b}}$ & $367.5^{\mathrm{b}}$ & $0.8272^{b}$ & $3.2587^{\mathrm{b}}$ & $0.064^{\mathrm{b}}$ & $0.3638^{b}$ \\
\hline Mixed culture & $26.87^{\mathrm{c}}$ & $206.5^{\mathrm{c}}$ & $239.1^{\mathrm{c}}$ & $0.5364^{\mathrm{c}}$ & $2.2192^{\mathrm{c}}$ & $0.043^{b}$ & $0.2604^{\mathrm{c}}$ \\
\hline Mixed culture + AMF & $59.73^{\mathrm{a}}$ & $320.6^{\mathrm{a}}$ & $418.0^{\mathrm{a}}$ & $1.2121^{\mathrm{a}}$ & $4.4350^{\mathrm{a}}$ & $0.077^{\mathrm{a}}$ & $0.4194^{\mathrm{a}}$ \\
\hline$L S D_{(0.05)}$ & 2.85 & 18.64 & 19.78 & 0.24 & 0.58 & 0.01 & 0.05 \\
\hline \multicolumn{8}{|c|}{ Nutrient content in alfalfa $[\mathrm{mg} /$ nutrient/pot] } \\
\hline Monoculture & $2.52^{\mathrm{b}}$ & $18.5^{\mathrm{c}}$ & $16.1^{\mathrm{c}}$ & $0.0571^{\mathrm{c}}$ & $0.5968^{\mathrm{c}}$ & $0.0077^{\mathrm{c}}$ & $0.0279^{\mathrm{c}}$ \\
\hline Monoculture + AMF & $5.55^{\mathrm{a}}$ & $51.3^{\mathrm{a}}$ & $37.5^{\mathrm{a}}$ & $0.1619^{\mathrm{a}}$ & $1.6833^{\mathrm{a}}$ & $0.0145^{\mathrm{a}}$ & $0.0684^{\mathrm{a}}$ \\
\hline Mixed culture & $2.28^{\mathrm{b}}$ & $14.2^{\mathrm{d}}$ & $12.6^{\mathrm{d}}$ & $0.0539^{c}$ & $0.4910^{\mathrm{c}}$ & $0.0050^{\mathrm{d}}$ & $0.0253^{\mathrm{c}}$ \\
\hline Mixed culture $+\mathrm{AMF}$ & $5.62^{\mathrm{a}}$ & $29.3^{\mathrm{b}}$ & $31.5^{\mathrm{b}}$ & $0.1282^{b}$ & $1.1497^{\mathrm{b}}$ & $0.0126^{\mathrm{b}}$ & $0.0602^{\mathrm{b}}$ \\
\hline$L S D_{(0.05)}$ & 0.26 & 2.4 & 2.2 & 0.01 & 0.15 & 0.001 & 0.007 \\
\hline
\end{tabular}

Means within a column followed by different letters are significantly different $(P<0.05) ; L S D$ - least significant difference; Nutrient content $[\mathrm{mg} / \mathrm{pot}]=$ nutrient concentration $[\mathrm{mg} / \mathrm{g}] \times$ dry matter. 
Higher P content in AM plants observed in this study, agrees with earlier studies (Smith \& Read 1997; Clark \& Zeto 2000). AMF might increase P acquisition of plant by enhanced exploration of soil $\mathrm{P}$ not available to plant roots by the external mycelium, and increase $\mathrm{P}$ solubilisation by AM root exudates which resulted in an increase in $\mathrm{P}$ content of soils. The ability of AMF to increase plants uptake of $\mathrm{Cu}, \mathrm{Mn}, \mathrm{Zn}$ and $\mathrm{Fe}$ is well documented (Liu et al. 1994; Ibrahim 2010). The increase in micronutrients absorption might be due to a better exploration of the soil by the AM hyphae and to a greater $\mathrm{P}$ and water uptake of AM plants (Davies et al. 2005; Smith \& Read 2008). On the other hand, AMF tend to produce more $\mathrm{CO}_{2}$ in the rhizosphere soil (Mohammad et al. 2005), causing an decrease in soil $\mathrm{pH}$ and eventually the availability of nutrients. Higher nutrients content achieved by mixed culture compared to monoculture, may indicate that the mixed culture used plant growth resources more efficiently than sole crop (Fukai \& Trenbath 1993). The decrease in selected nutrients content in alfalfa compared to cotton was partly a reflection of differences in dry matter. Plants facilitation and/or competition may depend on the identity and diversity of AMF species (Walder et al. 2012), the size and age of the plants (van der Heijden \& Horton 2009), and the supply levels of important nutrients. Higher nutrients content in cotton may indicate that cotton can be more competitive than alfalfa in soils where nutrients availability is reduced. The higher competitive ability might be due to the greater root length of cotton and faster root growth compared to alfalfa. The complementarity resource use between cotton and alfalfa could be enforced by AMF resulting in competitive enhancement of AM cotton. The lower nutrients contents in mixed alfalfa could be due to the decrease in the nutrients concentrations in the rhizosphere of alfalfa plants, leading to markedly decreased content in tissues.

The chlorophyll content in a plant depends on the ability of nitrogen adsorption by the plant, and this is considered an important factor in farm management (Jongschaap \& Booij 2004). In the present study, the increase in chlorophyll concentration of cotton leaf in mixed culture compared to monoculture could be attributed to the increase in nitrogen fixation by alfalfa and to higher usage of available nitrogen in the soil. Many studies showed higher leaf chlorophyll content in the intercropping than monoculture (Tsubo et al. 2005; Ghosh et al. 2006). According to Ghosh et al. (2006), the higher chlorophyll content of sorghum leaf in intercropping of soybean/sorghum was attributed to the overcast of plants on each other and nitrogen fixation by legume in intercropping. On the other hand, improved micronutrients uptake play an important role in biosynthesis of chlorophyll, proteins and secondary metabolites (Rengel 1999; Subramanian et al. 2009; Parmar et al. 2012). Also, providing legume with $\mathrm{P}$ and other immobile nutrients could support nitrogen fixation of legume (Clark \& Zeto 2000). Therefore, the transfer of fixed $\mathrm{N}$ to cotton may contribute improvement of chlorophyll content in cotton. Decreased chlorophyll ratio a:b in AM mixed culture was due to increase of chlorophyll $b$, which might be due to increased plants shading on one another. Under the shade conditions, plants tend to increase their content of chlorophyll to trap more light.

It seems that AMF has a role in increasing the availability of cotton to nitrogen sources and increasing the protein concentration. Increased protein concentration in mixed culture is in agreement with the results of Herbert et al. (1984) and Najafi et al. (2013) who showed that protein content were higher in mixed compared to monoculture. Fixing of atmospheric nitrogen by alfalfa and its transfer to cotton can increase protein in the mixed culture. Many researches showed that the fixed nitrogen is transferred to intercrop (Xiao et al. 2004; Wahbi et al. 2016). Both nitrogen transfer (fixed nitrogen and residual nitrogen) can reduce the cost of the nitrogen supply in legume-based intercropping different systems (Willy 1990). Increased crude protein by AM mixed culture indicates the importance of this culture pattern in improving quality of alfalfa as animal feed. The dry matter weight of cotton grown in mixed culture was greater than monoculture. Experimental results obtained by Kulandaivel et al. (2001) reported that dry matter production of cotton was significantly higher in cotton/blackgram intercropping than sole cropping. Highest cotton dry matter values found in AM mixed culture is in agreement with the results of Pellegrino and Bedini (2014). This may be attributed to the improvement of nutrient uptake (Jia et al. 2004). Improving uptake of 
micronutrients by AMF could induce plant chlorophyll content and photosynthesis, and consequently, increase biomass production (Tilak et al. 1992).

\section{CONCLUSIONS}

The results clearly showed that the application of AMF in cotton/alfalfa mixed culture had a positive effect on the chemicals and biochemical constituents in cotton shoot. Enhanced chlorophyll and protein concentration of AM cotton plants can be attributed to enhanced mineral nutrition by AMF and the effect of alfalfa on nitrogen status in cotton. Improved chemicals and biochemical constituents in cotton led to an increase in the dry matter production.

Acknowledgements. The author is grateful to the Atomic Energy Commission of Syria (AECS) for encouragement and technical support.

\section{REFERENCES}

ARNON, D.I. 1949. Copper enzymes in isolated chloroplasts: Polyphenoloxidase in Beta vulgaris. In Plant Physiology, vol. 24 , pp. $1-15$

BOHRER, G. - KAGAN-ZUR, V. - ROTH-BEJERANO, N. - WARD, D. - BECK, G. - BONIFACIO, E. 2003. Effects of different Kalahari-desert VA mycorrhizal communities on mineral acquisition and depletion from the soil by host plants. In Journal of Arid Environments, vol. 55, pp. 193 208. DOI: 10.1016/S0140-1963(03)00047-8

CLARK, R.B. - ZETO, S.K. 2000. Mineral acquisition by arbuscular mycorrhizal plants. In Journal of Plant Nutrition, vol. 23, pp. 867-902. http://dx.doi. org/10.1080/01904160009382068

DERELLE, D. - COURTY, P.E. - DAJOZ, I. - DECLERCK, S. - Van AARLE, I.M. - CARMIGNAC, D. - GENET, P. 2015. Plant identity and density can influence arbuscular mycorrhizal fungi colonization, plant growth, and reproduction investment in coculture. In Botany, vol. 93, no. 7, pp. 405-412. https://doi.org/10.1139/cjb-2014-0180

DAVIES, J. - CALDERON, M.C. - HUAMAN, Z. 2005. Influence of arbuscular mycorrhizae indigenous to peru and a flavonoid on growth, yield, and leaf elemental concentration of yungay potatoes. In HortScience, vol. 40, pp. 381-385.

FUKAI, S. - TRENBATH, B.R. 1993. Processes determining intercrop productivity and yields of component crops. In Field Crops Research, vol. 34, pp. 247-271. https://doi. org/10.1016/0378-4290(93)90117-6

GAO, Y. - WU, P.T. - ZHAO, X.N. - WANG, Z.K. 2014. Growth, yield, and nitrogen use in the wheat/maize intercropping system in an arid region of north western China. In Field Crops Research, vol. 167, pp. 19-30. DOI: 10.1016/j. fcr.2014.07.003

GHOSH, P.K. - MANNA, M.C. - BANDYOPADHYAY, K.K. - AJAY, A.K. - TRIPATHI, R.H. - WANJARI, KM. et al. 2006. Interspecific interaction and nutrient use in soybean/sorghum intercropping system. In Agronomy Journal, vol. 98, pp. 1097-1108. http://dx.doi.org/10.2134/agronj2005.0328

GIOVANNETTI, M. - MOSSE, B. 1980. An evaluation of techniques for measuring vesicular-arbuscular mycorrhizal infection in roots. In New Phytologist, vol. 84, pp. 489-499. DOI: 10.1111/j.1469-8137.1980.tb04556.x

HAUGGAARD-NIELSEN, H. - GOODING, M. - AMBUS, P. - CORRE-HELLOU, G. - CROZAT, Y. - DAHLMANN, C. et al. 2009. Pea-barley intercropping for efficient symbiotic $\mathrm{N}_{2}$-fixation, soil $\mathrm{N}$ acquisition and use of other nutrients in European organic cropping systems. In Field Crops Research, vol. 113, pp. 64-71. DOI: 10.1016/j.fcr.2009.04.009

van der HEIJDEN, M.G.A. - HORTON, T.R. 2009. Socialism in soil? The importance of mycorrhizal fungal networks for facilitation in natural ecosystems. In Journal of Ecology, vol. 97, pp. 1139-1150. DOI: 10.1111/j.13652745.2009.01570.x

HERBERT, S.J. - PUTNAM, D.H. - POOS-FLOYD, M.I. VARGAS, A. - CREIGHTON J.F. 1984. Forage yield of intercropped corn and soybean in various planting patterns. In Agronomy Journal, vol. 76, pp. 507-510. DOI:10.2134/ agronj1984.00021962007600040001x

IBRAHIM, M. 2010. Influence of arbuscular mycorrhizal fungi $(A M F)$ on the nutrition of the cotton (Gossypium hirsutum $\mathrm{L}$.) and its tolerance to water stress.PhD, Liege-Gembloux Agro-BioTech. Belgium.

JIA, Y. - GRAY, V.M. - STRAKER, C.J. 2004. The Influence of rhizobium and arbuscular mycorrhizal fungi on nitrogen and phosphorus accumulation by Viciafaba. In Annals of Botany, vol. 94, pp. 251-258. DOI: 10.1093/aob/mch135

JONGSCHAAP, R.E.E. - BOOIJ, R. 2004. Spectral measurements at different spatial scales in potato: Relating leaf, plant and canopy nitrogen status. In International Journal of Applied Earth Observation and Geoinformation, vol. 5, pp. 205-218. https://doi.org/10.1016/j.jag.2004.03.002

KHUDER, A. - SAWAN, M.KH. - KARJOU, J. - RAZOUK, A.K. 2009. Determination of trace elements in Syrian medicinal plants and their infusions by energy dispersive $\mathrm{X}$-ray fluorescence and total reflection X-ray fluorescence spectrometry. In Spectrochimica Acta Part B, vol. 64, pp. 721-725. DOI: 10.1016/j.sab.2009.05.020

KLIRONOMOS, J.N. 2003. Variation in plant response to native and exotic arbuscular mycorrhizal fungi. In Ecology, vol. 84, pp. 2292-2301. DOI: 10.1890/02-0413

KULANDAIVEL, S.R. - BHOOPATHI, KUMAR, P. - GURUMURTHY, S. 2001. Effect of planting pattern on cotton-based intercropping system. In Annals of Agricultural Research, vol. 22, no 1, pp 64-66.

LIU, R.J. - SHEN, C.Y. - QIU, W.F. 1994.The effect of VAM fungi on growth and yield of cotton. In Acta AgriculturaeUniversitatis Pekinensis, vol. 20, pp. 88-91.

MOHAMMAD, M.J. - PAN, W.L. - KENNEDY, A.C. 2005. Chemical alteration of the rhizosphere of the mycorrhizal-colonized wheat root. In Mycorrhiza, vol. 15, pp. 259266. DOI: $10.1007 / \mathrm{s} 00572-004-0327-0$

MOSSE, B. 1986. Mycorrhiza in a sustainable agriculture. In Biology Agriculture and Horticulture, vol. 3, pp.143-152.

McDONALD, P. - HENDERSON, A.R. - HERO, S.J.E. 1991. The Biochemistry of Silage. Marlow, UK : Chalcombe publications, pp. 9-340.

NAJAFI, N. - MOSTAFAEI, M. - DABBAGH, M.N.A OUSTAN, S.H. 2013. Effect of intercropping and farmyard manure on the growth, yield and protein concentration of corn, bean and bitter vetch. In Journal of Agricultural Science, vol. 23, no.1, pp. 99-116. 
PARMAR, P. - PATEL, M.J. - DAVE, B - SUBRAMANIAN, R.B. 2012. Nickel accumulation by Colocassia esculentum and its impact on plant growth and physiology. In African Journal of Agricultural Research, vol. 7, no. 24, pp. 35793587.

PELLEGRINO, E. - BEDINI, S. 2014. Enhancing ecosystem services in sustainable agriculture: biofertilization of chickpea (Cicer arietinum L.) by arbuscular mycorrhizal fungi. In Soil Biology and Biochemistry, vol. 68, pp. 429-439. DOI: 10.1016/j.soilbio.2013.09.030

REIJNTJES, C. - HAVERKORT, B. - WATERS-BAYER, A. 1992. Farming for the future, an introduction to low-external-input and sustainable agriculture. London, UK : Macmillan Education Ltd, 250 p.

RENGEL, Z. 1999. Physiological mechanisms underlying differential nutrient efficiency of crop genotypes. In RENGEL, Z. (Ed.) Mineral nutrition of crop. NY : Food Products Press, pp. 227-266.

SAS INSTITUTE INC. 2004. SAS user's guide: statistics version 9.1.2. SAS Institute Inc, Cary, NC.

SIEVERDING, E. 1991. Vesicular-arbuscular mycorrhiza management in tropical agrosystems. Technical cooperation, Germany : Eschborn. pp. 371.

SIQUEIRA, J.O. - COLOZZI-FILHO, A. - FARIA, F.H.S. OLIVEIRA E. 1986. Symbiotic effectiveness of vesicular arbuscular mycorrhizal fungal species in cotton. In Revista Brasileira de Ciencia do Solo, vol. 10, pp. 213-218.

SMITH, S.E. - READ, D.J. 1997. Mycorrhizal Symbiosis, 2nd edition. London, UK : Academic Press. pp. 605.

SMITH, S.E. - READ, D.J. 2008. Mycorrhizal Symbiosis, 3rd edition. Cambridge: Academic Press, UK. pp. 787.

SUBRAMANIAN, K.S. - TENSHIA, V. - JAYALAKSHMI, K. - RAMACHANDRAN, V. 2009. Role of arbuscular mycorrhizal fungus (Glomus intraradices) - (fungus aided) in zinc nutrition of maize. In Journal of Agricultural Biotechnology and Sustainable Development, vol. 1, no. 1, pp. 029-038. http://www.academicjournals.org/JABSD
TILAK, K.V.B.R. - SINGH, C.S. - ROY, N.K - SUBBA RAO, N.S. 1992. Azospirillumbrasilense and Azotobacterchrococcum inoculum effect on maize and sorghum. In Soil Biology and Biochemistry, vol. 14, pp. 417-418. http://dx.doi. org/10.1016/0038-0717(82)90016-5.

TSUBO, M. - WALKER, S. - OGINDO, H.O. 2005. A simulation model of cereal legume intercropping systems for semi-arid regions. Model application. In Field Crops Research, vol. 93, pp. 23-33. DOI:10.1016/j.fcr.2004.09.003

VANDERMEER, J.H. 1989. The ecology of intercropping systems. Cambridge : Cambridge university, $237 \mathrm{pp}$.

WAHBI, S. - MAGHRAOUIB, T. - HAFIDI, M. - SANGUIN, H. - OUFDOU, K. - PRIN, Y. - DUPONNOIS, R. - GALIANA, A. 2016. Enhanced transfer of biologically fixed N from fababean to intercropped wheat through mycorrhizal symbiosis. In Applied Soil Ecology, vol. 107, pp. 91-98. https://doi.org/10.1016/j.apsoil.2016.05.008

WILLY, R.W. 1990. Resource use in intercropping systems. In Journal of Agriculture Water Management, vol. 17, pp. 215-231. https://doi.org/10.1016/0378-3774(90)90069-B

XIAO, Y. - LI, L. - ZHANG, F. 2004. Effect of root contact on interspecific competition and $\mathrm{N}$ transfer between wheat and faba bean using direct and indirect ${ }^{15} \mathrm{~N}$ techniques. In Plant and Soil, vol. 262, pp. 45-54. DOI: 10.1023/B:PLSO.0000 037019.34719.0d

WALDER, F. - NIEMANN, H. - NATARAJAN, M. - LEHMANN, M.F. - BOLLER, T. - WIEMKEN, A. 2012. Mycorrhizal networks: common goods of plants shared under unequal terms of trade. In Plant Physiology, vol. 159, pp. 789-797. https://doi.org/10.1104/pp.112.195727

Received: April 3, 2017 